\title{
Aneurisma gigante de artéria poplítea
}

\author{
Jennifer Naomi Kinoshita ${ }^{1}$, Sthefano Atique Gabriel ${ }^{2}$, \\ Otacilio de Camargo Junior ${ }^{2}$, Antonio Claudio Guedes Chrispim²
}

Kinoshita JN, Gabriel SA, Camargo Junior O, Chrispim ACG. Aneurisma gigante de artéria poplítez. Rev Med (São Paulo). 2015 jan.-mar.;94(1):70.

\section{INTRODUÇÃO}

O aneurisma de artéria poplítea é o aneurisma periférico mais frequente, podendo corresponder a $70 \%$ dos mesmos, sendo mais prevalente no sexo masculino onde é encontrado em torno de $95 \%$ dos casos. Estes aneurismas são de incidência bilateral em mais de $50 \%$ dos casos, podendo ter também uma associação de mais de 50\% com aneurisma de aorta abdominal. A complicação mais comum do aneurisma de artéria poplítea é a embolização distal sendo a complicação mais grave a trombose com risco alto de perda do membro. A rotura do aneurisma de poplítea é rara com uma incidência de menos de $3 \%$, porem, dependendo do tamanho a rotura pode representar um risco maior para o paciente.

\section{OBJETIVO}

Relatar o caso de um paciente do sexo masculino, que chegou em nosso serviço com quadro clínico de dor importante em membro inferior direito. Ao exame físico apresentava massa pulsátil em região poplítea direita sem sinais de isquemia do membro.

\section{RELATO DE CASO}

Paciente do sexo masculino, 56 anos, com diagnóstico clínico de aneurisma de artéria poplítea foi submetido a exame de eco-color-Doppler em membro inferior direito com confirmação diagnóstica, apresentando aneurisma gigante de artéria poplítea de $5,3 \mathrm{~cm}$. Realizado também tomografia contrastada e angiografia do membro. Paciente submetido a tratamento cirúrgico com ressecção do saco e interposição de enxerto com veia safena invertida. Paciente apresentou boa evolução, sem dor ou isquemia no pós-operatório recebendo alta hospitalar no terceiro dia pós-operatório.

\section{DISCUSSÃO}

O enxerto fêmoro-poplíteo é o tratamento de escolha nos casos de aneurisma de artéria poplítea.

\section{CONCLUSÃO}

O aneurisma de artéria poplítea é o aneurisma periférico mais frequente com alta taxa de complicações embólicas e trombóticas, e com baixa taxa de rotura, porém, quando não diagnosticado apresentando-se muito dilatado pode apresentar muita dor por compressão de estruturas vizinhas com um maior risco de rotura. Deve sempre ser diagnosticado e se tiver indicação tratado precocemente antes de apresentar complicações.

\footnotetext{
$2^{\circ}$ lugar Prêmio Painéis - Área Relato de Caso no $33^{\circ}$ COMU - Congresso Médico Universitário da FMUSP, SP, 31 de out. a 02 de nov. de 2014.

1. Acadêmica de Medicina da Faculdade de Medicina da Universidade de São Paulo.

2. Orientadores, Faculdade de Medicina da Universidade de São Paulo.
} 